\title{
CAPITALISING ON MOBILE INSTANT MESSAGING FOR UNDERGRADUATES BUSINESS EMPOWERMENT
}

\author{
Che Faridah Che Mahmood ${ }^{1}$, Nazihah Omar' ${ }^{1}$, \\ Norshaieda Adnan@ Abdullah ${ }^{2}$ and Nor Balkish Zakaria ${ }^{3}$ \\ ${ }^{1}$ Faculty of Business and Management, \\ Universiti Teknologi MARA Cawangan Johor, Segamat, Johor \\ ${ }^{2}$ Faculty of Science Computer and Mathematics, \\ Universiti Teknologi MARA Cawangan Johor, Segamat, Johor \\ ${ }^{3}$ Accounting Research Institute, \\ Universiti Teknologi MARA Cawangan Johor, Segamat, Johor \\ E-mail: norbalkish@uitm.edu.my
}

\begin{abstract}
Mobile Instant Messaging (MIM) or Instant Messaging (IM) via various web-based applications like WeChat, Viber, WhatsApp (WA) and Snapchat have gained much attention. It allows mobile phone users to access instant messaging services right from their smartphones. Despite various general publications indicating the advantages of mobile business, ranging from the start-up cost, flexibility, mobility up to inventory, the MIM's application via mobile businesses are still scarce. The aim of this study was to examine the realm of MIM usage as a platform for mobile business among undergraduates in Malaysia by examining the uses of MIM for mobile business and to identify the perceived advantages of MIM as a platform for mobile business. An online questionnaire was designed and randomly distributed among identified undergraduates who have actively engaged in mobile business. The results show that MIM is frequently used to advertise and sell products most needed by undergraduates. Among the perceived advantages of MIM as a platform for mobile business is its cost effectiveness. In addition, undergraduates can easily and conveniently startup mobile businesses and generate income simply via a mobile device and a mobile number as it is indeed preferable for reaching a general audience.
\end{abstract}

Keywords: mobile business, instant messaging, perceived advantages, undergraduates

ARTICLE INFO

Article History:

Received: 26 July 2019

Accepted: 24 October 2019

Published: 31 December 2019 


\section{INTRODUCTION}

Today's undergraduates, are born and raised to experience instant information and utility at their fingertips, have gone through changes in different facets of their lives. They live in a world of technological-gadgets proliferation that is by far different from that of their previous generations (Anderson \& Rainie, 2018). For instance, smartphone applications such as Mobile Instant Messaging (MIM) on diverse mobile platforms (e.g., iOS, Android, Symbian, and Windows) have become the gateway for entertainment, commerce, and work and have tremendously changed people's living habits and mode of operations (Ying \& Khe, 2017; So, 2016; Cukier \& MayerSchönberger, 2013). MIM, being widely adopted by young people due to its user-friendly features and convenience for customers is regarded as a powerful device in our daily life (Fondevila-Gascón et al., 2019; Bhatt \& Arshad, 2016). Among the MIM applications, WA, Telegram, Viber and Line allow mobile users to send and receive messages, pictures, videos, and audios to individuals or group of friends at no cost (Karimiyazdi \& Mokhber, 2015). Such a cost factor can surely attract young adults to be involved enthusiastically in online activities. A review of literature has shown that MIM has many advantages over the traditional communication tools such as social networking sites and Short Message Service (SMS) (Gan \& Li, 2015). The advantages of MIM, together with the convenience of mobile data plan, have resulted in MIM being forecasted to continuously grow and lead significant decreases in SMS traffic.

Business people around the world are also finding ways to benefit from this application. The fact that customers are being connected all the time and anywhere is a great opportunity to advertise, build, and develop customer relationships, and receive direct response from them (Dusto, 2014; ChanOlmsted et al., 2013). The study conducted by Church and Oliveira (2013) who interviewed active MIM users revealed that intents people use MIM for business related communication and receiving advertisements. Most of these active MIM users are young adults whom researchers anticipate, are inclusive of undergraduates. As also mentioned by Hwang (2012), innovative technology via smartphone applications may help to empower businesses to expand their products all over the world. It can be seen that social networking has made it easy to promote while taking and receiving orders from customers around the world. The study conducted by Ibrahim 
et al. (2014) found the benefits of WA and Facebook and have highlighted positive reactions towards these applications especially in social application to businesses. In the coming years, many predict that messaging applications will become the primary way customers communicate with brands. It is said that brands will move away from communicating through social networks and switch to direct communications via messaging services such as WA, Facebook Messenger, Skype, Google Hangouts and Viber (Benady, 2016).

The advancement of smartphone applications has also provided entrepreneurial opportunities. For example, WA enables young entrepreneurs, the IT-savvy, to enrich sales messages with entertainment features in their marketing campaign (Nawi et al., 2016). It is found that there is a relatively large number of undergraduates who became mobile entrepreneurs during college and used various social media and mobile applications for their marketing strategies (Business Insider, 2016; Usahawan.com, 2016; Steimle, 2016).

Hence this paper aims to study the realm of MIM usage as a platform for mobile business among undergraduates by examining the different kinds of uses of MIM as a platform for mobile businesses among undergraduates and to identify undergraduates perceived advantages of MIM as a platform for mobile business.

The next section reviews the literature while the methodology section highlights the sampling and data collection procedures. Next, the finding section discusses the study results with the interpretations and finally the last section concludes the overall study.

\section{LITERATURE REVIEW}

Among all mobile instant messengers (MIM) available, WA in particular is the most popular global mobile messenger app worldwide with approximately 1.6 billion monthly active users in 2019. As reported by Reuters Institute, (2018) Malaysians are the world's largest users of WhatsApp at 54 per cent, an increase of $15 \%$ since 2014 . The increase in the WA adoption has affected communication patterns across the globe, information sharing and news consumptions to name a few. As for the Millennial generation, 
today which comprises of undergraduates, it is reported that they have actively adopted WA as a convenient communication tool for issues related to university affairs apart from their personal lives (Fondevila-Gascón et al., 2019). Research on the adaptation of WA as a mobile learning tool are aplenty (Kootbodien et al., 2018; Ugwu \& Anekwe, 2018; Ying \& Khe, 2017; Luaran et al., 2016; So, 2016).

However, studies on WA's penetration by the young adults particularly undergraduates in online marketing or mobile business are still lacking. Researchers believe that if MIM applications like WA are widely used and well accepted in mobile learning, these applications can also be utilized for other purposes - which include mobile shopping and selling. As revealed by Ibrahim et al. (2014) smartphone applications give a positive impact to online business success. For instance, Instagram, an interactive and innovative photo-sharing application allows companies and vendors to share product information, photos or pictures thus speeding up communication with potential customers (Ting et al., 2015). The combination of visual graphics and text retains more impact and is far more engaging than text alone. In a study by Benady (2016), messaging is seen as the next big opportunity to business because it allows a direct and more personalised relationship with customers rather than people broadcasting on social networks, thus enabling conversation and creating a compelling consumer experience.

Back in 2010, Salamon and Wahab found that high involvement in multi-level marketing among undergraduates was due to a lack of fund to support their college expenses. These undergraduates have turned themselves to become online/mobile sellers as an alternative for them to earn an extra income in the efforts to pay their way through college. Their efforts become possible with the availability of diverse applications in smart phones thus they present opportunities to offer different mobile business strategies ever before (Olmstead, 2014; Yingjiao \& Paulins, 2015). The current scenario shows that the undergraduates can forge their own paths by starting their own businesses across a wide variety of industries (Bush, 2019; Kuligowski, 2019; Lopez; 2019). 


\section{Uses of MIM as A Platform for Mobile Business}

MIM applications open the door for undergraduates as mobile marketers to be creative in their mobile business. In conducting a mobile business, marketers need to weigh on the types of products advertised (Drossos \& Fouskas, 2010; Ma et al., 2009), type of message service sent to users (Koo et al., 2012) and some design attributes of mobile advertising (Chen \& Hsieh, 2012). Thus the uses of WA for mobile business can be capitalized on these aspects to reach the audience, capture their undivided attention and prompt their quick responses. According to the current Smart Insights report by Chaffey (2016), 89 percent of customers' mobile time are spent on applications. Given such a high statistic, approaches for selling, advertising and post-sales/after-sales service on mobile business should be conducted creatively.

In a college environment, products or services offered should be the ones needed by the undergraduates themselves. In an article by Khalil (2014) on the business ideas that Malaysian undergraduates could offer were prepaid phone card/prepaid online top ups, food \& beverage (readyto-eat/room-to-room delivery), photocopying service, proof reading, T-shirt printing, laptop repairs/service and laundry service. A recent report in "50 Best Small Business ideas for College Students for 2016" also highlighted sales of call cards and data bundles for different network service providers, jewellery and fashion accessories, gourmet business, and home tutor services to name a few. Undergraduates also like to shop online for apparel products (Yingjiao \& Paulins, 2015). While Anderson (2011) found that one of the ten things undergraduates waste money is on food. This thus shows that undergraduates can actually tap an opportunity to offer food service delivery via mobile applications to their friends.

In terms of mobile advertising, marketers should need to send unique, personalized and customized advertisements and engage their customers in discussions and transactions (Salo \& Tahtinen, 2009). A study by Parreño et al. (2013) also showed a similar result that mobile marketers can influence their customers' attitudes towards their products offerings through message personalization, content relevance and enriching the sales messages with entertainment features. While the study by Saadeghvaziri (2011) indicated that customers hold positive attitudes toward mobile advertisings and perceive them as informative. 
Mobile marketers may lose the chance to make their customers loyal users if the products/services do not meet customers' requirements, hence dissatisfaction may occur. Fazlzadeh et al. (2011) found that after-sales service quality impacted the overall offering in which customer's satisfaction could affect behavioural intentions and the quality of the relationship with customers. By using appropriate mobile marketing tools such as following up with the customers just after the purchase to get their immediate feedback may lead to more satisfactory post-purchase experiences for customers.

\section{Perceived Advantages of MIM as A Platform for Mobile Business}

There are various studies conducted that indicate MIM applications thus far offer many advantages. For education purposes, ample research found that most institutions of higher learning are willing to use both text and instant messaging to further enhance the learning process (Fondevila-Gascón et al., 2019; Kennedy et al., 2008). A study by Church and Oliviera (2013) in comparing MIM behaviour with traditional SMS found that WA offers benefits such as cost, sense of community and immediacy. Amry (2014), in her research shows a strong and positive impact of WA on the achievement and attitudes of female students towards educational technology based mobile devices.

Most of the existing MIM applications allow group chat, which provides a more efficient way for undergraduates to market specific products/ services or exchange information without delay and at no cost (Church \& Oliviera, 2013). Having the group-chat feature aids mobile marketers to create different segments (groups) within the applications. Thus it is an easier and faster method to advertise and sell the products/services which are more personal with unique messages and tailored to specific groups. Collier (2015) stated that "WA offers marketers a unique opportunity to tap into a highly engaged audience and build a list of customers who want to hear about your businesses". This is supported by Torok (2015) that "Messages sent via messaging applications are opened and read within a few minutes, so the message delivering is much more effective."

Looking at the research on MIM from the perspective of mobile learning, it can be said that MIM has advantages on the way the learning 
process is conducted. Perhaps MIM can also benefit marketers in managing their businesses. However, the uses of MIM as a primary platform for a mobile business and the perceived advantages gained are yet to be conclusive. Thus there is a need to further investigate the pivotal role of MIM in mobile businesses among undergraduates. It is hoped that the findings of the study will help to further understand the uses and potential benefits (if any) of MIM among undergraduates in conducting mobile businesses. If benefits are revealed, then MIM is indeed one of the alternatives for undergraduates to engage in online businesses. Otherwise, some other mobile messengers need to be tested for its benefits and as alternative marketing strategy for mobile business. Thus, the purpose of this study was to understand the different kinds of uses of MIM and its perceived advantages as a platform for a mobile business among young adults in particular undergraduates in Malaysian higher learning institutions.

\section{METHODOLOGY}

Primary data was collected using a purposive sampling approach via an online questionnaire. The online questionnaires were sent to identified undergraduates of Universiti Teknologi MARA who were found active in mobile business through students' activity records. The link of the questionnaire was sent via messaging applications either WA or Telegram. The questionnaire consisted of 3 sections and 15 items with mixed closed ended, open ended and 5 Likert scale questions. Section 1 captured the demographic information (6 items), section 2 was on undergraduates' involvement in mobile business ( 7 items) and section 3 related to undergraduates perceived advantages of using the MIM as a platform for mobile businesses ( 2 items).

A sample of 160 respondents completed the survey but 5 responses were discarded due to incompletion. Thus, a net sample of 155 usable questionnaires remained. Data analysis was conducted using the SPSS version 21 . Percentage analysis and cross tabulations analysis were used to answer the research questions. The results are presented in the form of tables and charts. 


\section{FINDING, ANALYSIS AND DISCUSSION}

\section{The Respondents' Profiles}

Out of 155 completed questionnaires, the respondents were mostly females with 78.2 percent compared to males with only 21.8 percent and they were aged between 19-25 years. Those involved in mobile business are above 20 years old with a total percentage of 94 percent. Out of this total, 20-year-old undergraduates presented 30.3 percent. This scenario shows that respondents get involved in mobile business as they begin their undergraduate study. A majority of them were pursuing their studies in business administration with 51.7 percent being in their second year. Table 1 shows the demographic characteristics of the respondents.

Table 1: Demographic Characteristics

\begin{tabular}{llc}
\hline & Demographic Characteristics & $\begin{array}{c}\text { Percentage } \\
\text { (\%) }\end{array}$ \\
\hline Gender & Male & 21.8 \\
& Female & 78.2 \\
\hline Age & 19 years old & 7.3 \\
& 20 years old & 32.7 \\
& 21 years old & 25.5 \\
& 22 years old & 20.0 \\
& More than 22 years old & 14.5 \\
\hline Involvement in traditional Business & Yes & 60.0 \\
& No & 40.0 \\
\hline
\end{tabular}

About 60 percent of the respondents were involved in face-to-face business transactions at the beginning of their business venture before switching to mobile business. The remaining 40 percent utilized the MIM applications in commencing their business. The result suggests that some grabed the opportunity to capitalize on current technology on starting-up the business while others on the sustainability of their existing business (Steimle, 2016). 


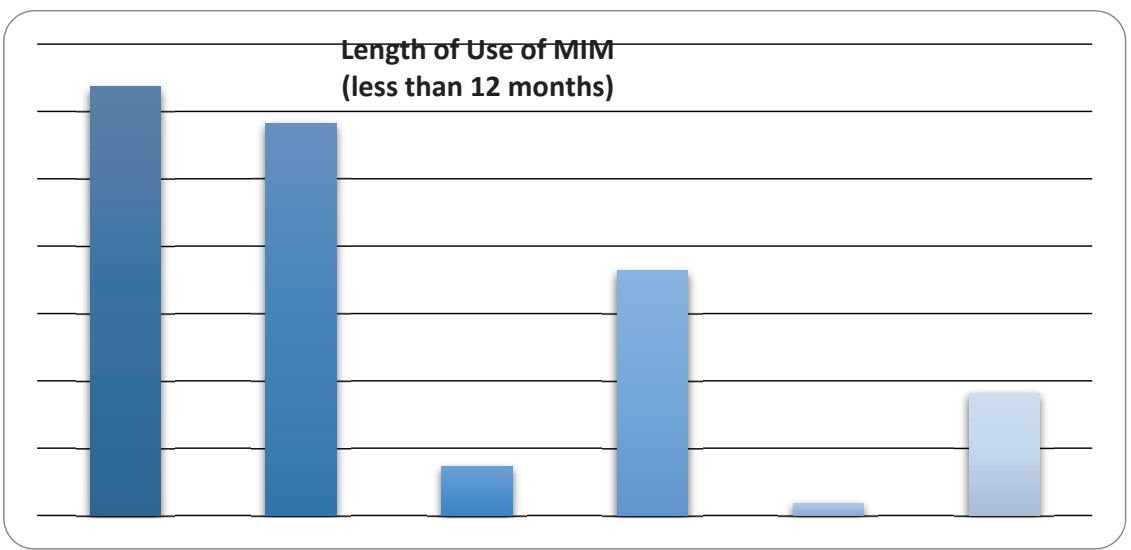

Chart 1: Length of Use of Mobile Instant Messaging

In the context of how long the undergraduates used MIM for mobile business, 64 percent had used it in less than 12 months. Most of the respondents in general had been using MIM for less than one year, however there are respondents who had been using it for more than 2 years. This result indicates that respondents' involvement in mobile businesses could have possibly begun at the age of 19. In general, most of them started their mobile businesses after socializing with their batch mates. In the interview conducted, five respondents revealed that they began using MIM after they got to know their batch mates first. Later they created group chats of select friends and shared information with them. Hence, this group-chat feature aids them to create different segments (groups) within the application, and indeed an easier and faster method to advertise and sell the products/ services (Collier, 2015).

\section{Products/Services Offering via Mobile Business}

The result shows undergraduates offered basic daily needs often requested by their college mates. Among these products or services, clothing scored the highest with 69.1 percent; food and beverage and cosmetics/ beauty products counted for 27.3 percent each; while prepaid phone cards is 23.6 percent. The rest of the products and services offered via a mobile business included electrical goods, books, telephones/accessories as well as health products. This result concurs with Yingjiao and Paulins (2015) that undergraduates shopped online for their clothing needs. The business 
ideas that undergraduates can take up as suggested by Khalil (2014) are also reflected in the result. The prepaid phone cards/prepaid online top ups as well as food and beverage are among the products sought after by undergraduates via mobile business.

With regard to which MIM applications that respondents used as their mobile business platform (respondents are allowed to choose more than one messaging applications), 93 percent chose WA, followed by 82 percent who chose Instagram, and WeChat, 47 percent. While Telegram and Viber were only 13 percent and 4 percent respectively. The result of WA being the main choice is consistent with the data presented by the Reuters Institute (2018) found that Malaysians are the world's largest users of WhatsApp at 54 percent. Instagram users in Malaysia reached 10.27 million in March 2019.

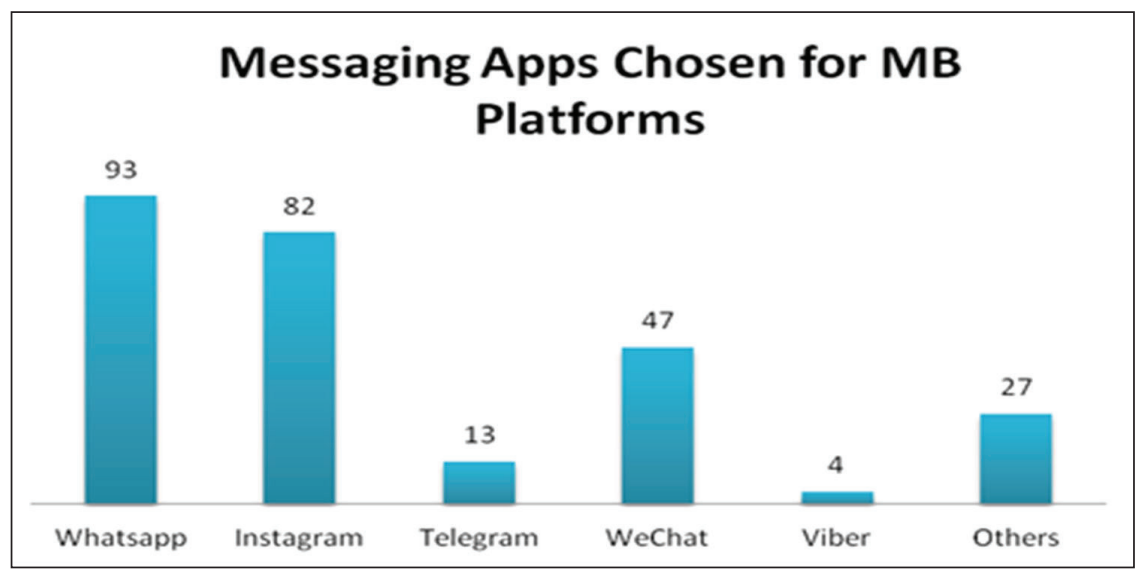

Chart 2: Messaging Applications chosen for Mobile Business Platforms

Respondents were asked to rate the frequency of usage of the chosen messaging applications. Chart 3 shows that the respondents frequently used WA (63 percent), followed by Instagram and WeChat with 55 percent and 42 percent, respectively. Most of the undergraduates will generally select and alternate the messaging applications that are preferred by their customers. This is due to specific features of messaging applications which are attractive and easier to use (Collier, 2015 \& Torok, 2015). 


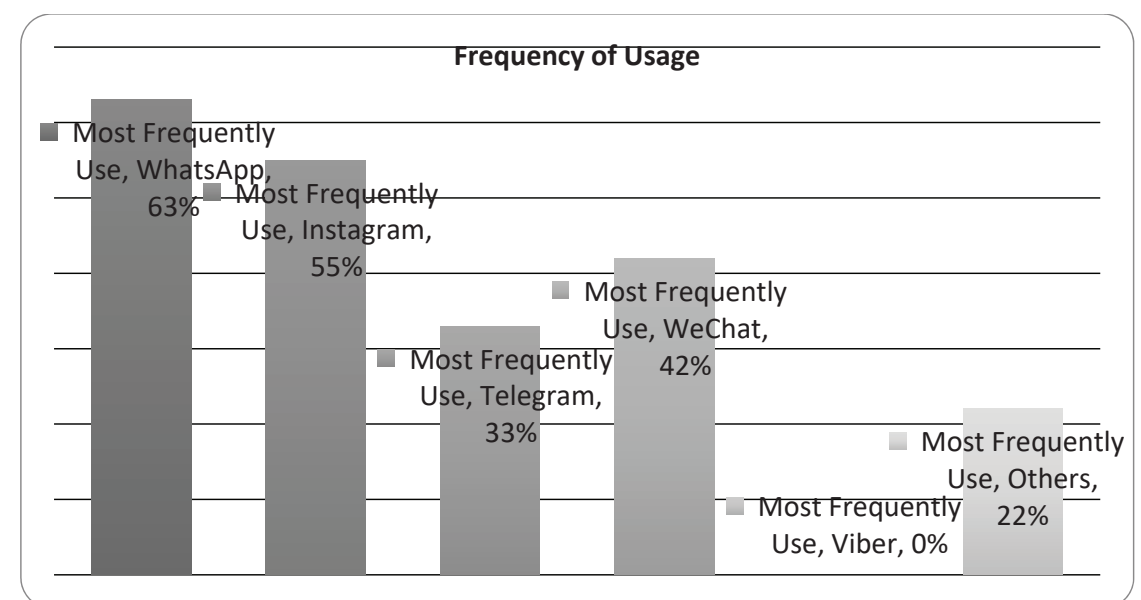

Chart 3: Usage Frequency of the Chosen Messaging Applications

\section{Main Uses of Chosen Messaging Applications for Mobile Business}

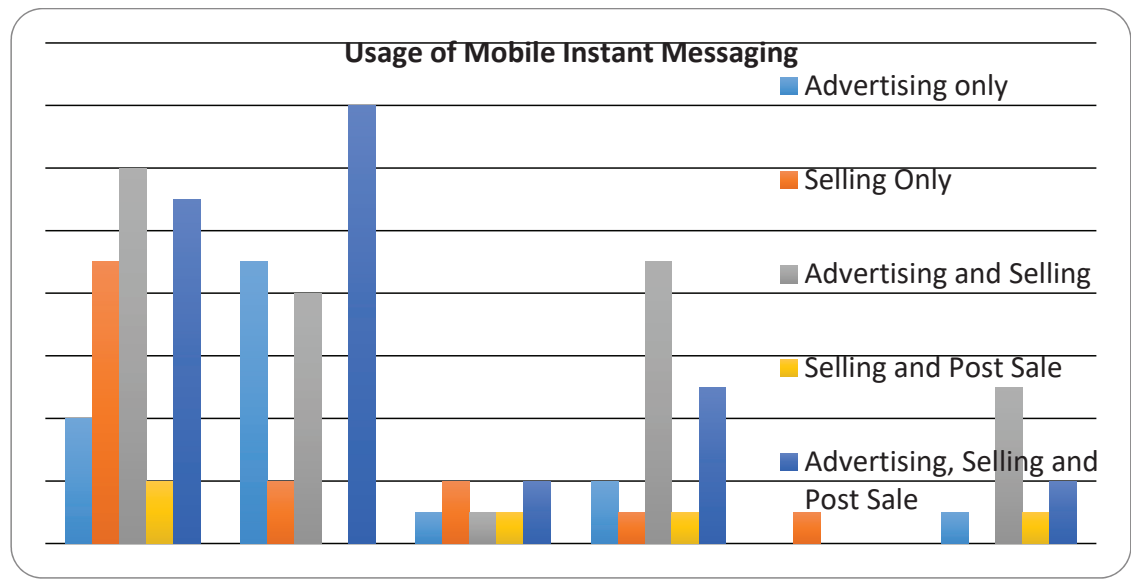

\section{Chart 4: Main Usage of Mobile Instant Messaging}

The above chart shows that, WhatsApp and WeChat are used mostly for advertising and selling products; however, Instagram was used widely for advertising, selling and post-sale. In terms of getting feedback and testimonials from customers, Instagram was found to be most convenient and user friendly. It is also found that clothing is the main product that is used for advertising and selling via Messaging Applications. WA is preferable 
to be capitalized for advertising and selling since more personal products/ services with unique messages can be sold and tailored to specific groups. The group-chat feature makes it easier and faster for the messages to be read within a few minutes (Torok, 2015).

\section{Perceived Advantages of MIM for Mobile Business Platform}

In addition to the uses of messaging applications, its perceived advantages for a mobile business was also examined (Chart 5). It was found that respondents use messaging applications for the purpose of generating an income and commencing a mobile business. This corresponds to the information stated in Businessinsider.my (2016) which highlights that today's Malaysian young entrepreneurs started venturing into mobile business during their tertiary study.

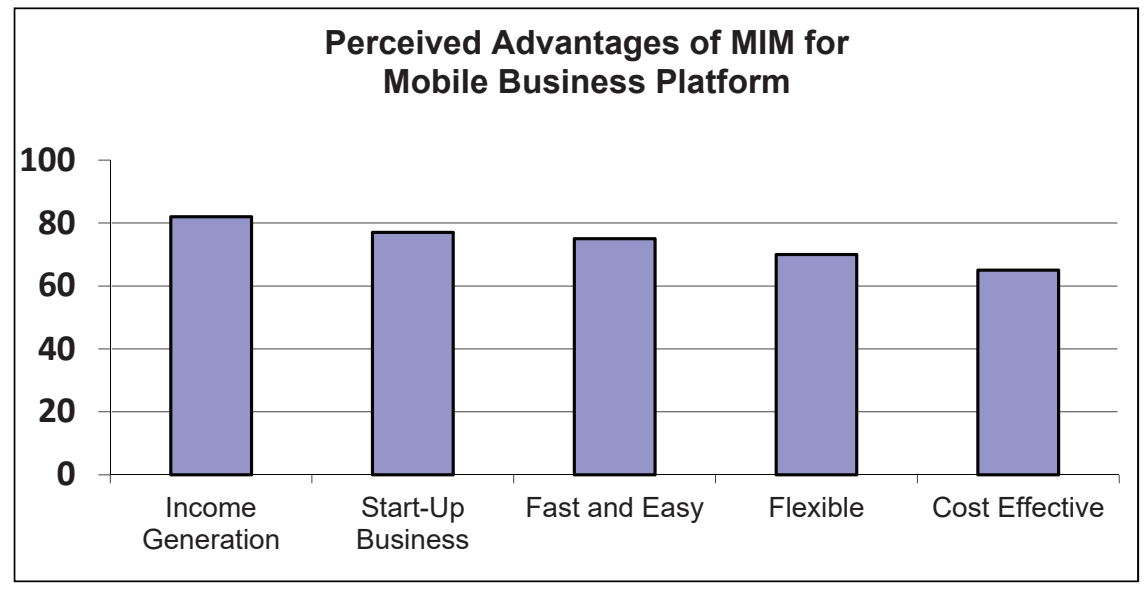

Chart 5: Perceived Advantages Using Messaging Applications for Mobile Business Platform

\section{CONCLUSION}

This paper aimed to investigate the uses of MIM for mobile business among undergraduates and to identify perceived advantages of MIM as a platform for mobile business. The results obtained show that mobile business among undergraduates is growing with the use for MIM for selling, advertising and post sales. However, undergraduates will utilize and alternate the messaging 
applications which features are convenient for their customers to know further about the products/services.

Among the perceived advantages of MIM for mobile business are for the undergraduates to make extra income in their efforts to pay their way through college. In addition, some undergraduates capitalize on MIM as a stepping stone for them to venture into mobile businesses. MIM features such as ease of use, document sharing and group chat offer easier and faster methods to advertise and sell products and services.

Several limitations were encountered in this study. Respondents are less likely to have internet access and to respond to online questionnaires. Even though this method is fast and convenient, some still prefer to answer printed questionnaires instead. In addition, most respondents were involved in the apparel business, thus the result may be different if the respondents' businesses are of different kinds. The study focussed on MIM alone and used the non-probability sampling technique, thus the results presented should not be generalized to other contexts or populations.

Future research can cross-validate across different samples and/ or virtual community settings. Future research may also investigate the effectiveness of messaging applications for mobile business; understanding the undergraduates' attitudes towards the use of messaging applications in business contexts; or examine the relationships between male and female undergraduates' attitudes towards the use of messaging applications.

\section{REFERENCES}

50 Best Small Business ideas for College Students for 2016. (n.d.). ProfitableVenture.com. Retrieved from http://www.profitableventure. com/business-ideas-for-college-students/

Amry, A. B. (2014). The impact of WhatsApp mobile social learning on the achievement and attitudes of female students compared with face to face learning in the classroom. European Scientific Journal, 10(22), 116-136. 
Anderson, J. \& Rainie, L. (2018). The Negatives of Digital Life. Pew Research Center. Retrieved from https://www.pewresearch.org/ internet/2018/07/03/the-negatives-of-digital-life/

Benady, D. (2016, July). Make the Connection. Catalyst. 4.

Bhatt, A., \& Arshad, M. (2016). Impact of WhatsApp on youth: A sociological study. IRA-International Journal of Management \& Social Sciences, 4(2), 376-386.

Bouhnik, D., Deshen, M., \& Gan, R. (2014). WhatsApp goes to school: Mobile instant messaging between teachers and students. Journal of Information Technology Education: Research, 13(1), 217-231.

Bush, R. (2019, April 17). 53 business ideas to start at university. Save the Student. Retrieved from https://www.savethestudent.org/makemone y/50-business-ideas-to-start-at-university.html

Chaffey, D. (2016). Global Social Media Research Summary 2016. Smart Insights. Retrieved from www.smartinsights.com/socialmedia.../socia l-media.../new-global-social- media-research/

Chaffey, D. (2016, October 26). Mobile Marketing Statistics Compilation. Smart Insights. Retrieved from http://www.smartinsights. com/mobilemarketing/mobile-marketing-analytics/mobile-marketing-statistics/

Chan-Olmsted, S., Rim, H., \& Zerba, A. (2013). Mobile news adoption among young adults: Examining the roles of perceptions, news consumption, and media usage. Journalism \& Mass Communication Quarterly, 90(1), 126-147.

Chen, P. T. \& Hsieh, H. P. (2012). Personalized mobile advertising: Its key attributes, trends and social impact. Technological Forecasting and Social Change, 79(3), 543-557.

Church, K., \& Oliveira, R. de. (2013). What's up with WhatsApp?: comparing mobile instant messaging behaviors with traditional SMS. Proceedings of the 15th international conference on Human-computer 
interaction with mobile devices and services (MobileHCI'13). 352-361. http://doi.org/10.1145/2493190.2493225

Collier, S. (2015, September 29). WhatsApp to Change Social Media Marketing? Practical Ecommerce. Retrieved from http://www. practicalecommerce.com/articles/79714-WhatsApp-to-Change-SocialMedia-Marketing

Cukier, K. \& Mayer-Schönberger, V. (2013). The rise of big data: How it's changing the way we think about the world. Foreign Affairs, 92(3), 2840. Retrieved from https://www.foreignaffairs.com/articles/2013-04-03/ rise-big-data

Drossos. D. A. \& Fouskas, K. G. (2010). Mobile Advertising: Product Development and Its Effect on Intention to Purchase. 2010 Ninth International Conference on Mobile Business and 2010 Ninth Global Mobility Roundtable (ICMB-GMR). 183-189. http://doi.org/10.1109/I CMB-GMR.2010.27

Dusto, A. (2014, April 2). Mobile messaging apps: The next mobile marketing frontier? Digital Commerce 360. Retrieved from https:// www.digitalcommerce360.com/2014/04/02/mobile-messaging-appsnext-mobile-marketing-frontier/

Fazlzadeh, A., Bagherzadeh, F., \& Mohamadi, P. (2011). How after-sales service quality dimensions affect customer satisfaction. African Journal of Business Management, 5(17), 7658-7664.

Fondevila-Gascón, J. F., Marqués-Pascual, J., Mir-Bernal, P., Polo-López, M. (2019). Uses of WhatsApp in the Spanish university student. Pros and cons. Revista Latina de Comunicación Social, 74, 308-324.

Gan, C. \& Li, H. (2015), Understanding continuance intention of mobile instant messaging. Industrial Management \& Data Systems, 115(4), 646-660.

Hidvegi, A. (2016). Assessing the Online Purchasing Decisions of Generation Z, Proceedings of FIKUSZ '16 Symposium for Young 
Researchers. 173-181. Retrieved from https://ideas.repec.org/h/tkp/ mklp17/331-335.html

Hwang, S. J. (2012). Investigation toward smartphone users' need before develop mobile application program, 5-6. Business Insider. Retrieved from http://www.businessinsider.my/tag/malaysia.

Ibrahim, J., Chee Ros, R. Sulaiman, N. F., Che Nordin, R. \& Li, Z. Y. (2014). Positive impact of smartphone application: Whatsapp \& Facebook for online business. International Journal of Scientific and Research Publications, 4(12). 1-4. http://www.ijsrp.org/research-paper-1214/

Idea Ini Boleh Bantu Pelajar Atasi Masalah Poket Kering. Usahawan. com. http://www.usahawan.com/idea-bisnes/cara-pelajar-menambahpendapatan-di-universiti.html

Karimiyazdi, R. \& Mokhber, M. (2015). Improving viral marketing campaign via mobile instant messaging (MIM) Applications. Journal of Advanced Review on Scientific Research, 10(1), 20-33.

Kennedy, G. E., Judd, T. S., Churchward, A., Gray, K., \& Krause, K. L. (2008). First year students' experiences with technology: Are they really digital natives? Australasian Journal of Educational Technology, 24(1), 108-122.

Khalil, S. (2014, April 25). 9 Idea Bisnes Untuk Mahasiswa Di Kampus. Majalah Niaga. Retrieved from https://www.majalahn iaga.com/bisnesdunia-kampus.html

Koo, W., Knight, D. K., Yang, K. \& Xiang, Z. (2012). Generation Y consumers' value perceptions toward apparel mobile advertising: Functions of modality and culture. International Journal of Marketing Studies, 4(2), 56-66.

Kootbodien, A. \& Prasad, N. \& Ali, M. (2018). Trends and impact of WhatsApp as a mode of communication among Abu Dhabi students. Media Watch, 9(2), 257-266. 
Lopez, J. (2019, July 19). Should You Start Your Own Business While Still in College? Business News Daily. Retrieved from https://www. businessnewsdaily.com/15202-before-you-start-a-business-in-college. html

Luaran, J., Jain, J. \& Abd Rahman, N. (2016). The use of WhatsApp group in class-related information sharing through academic discussion. International Journal on E-Learning and Higher Education, 4, 176194.

Ma, J., Suntornpithug, N. \& Karaatli, G. (2009). Mobile advertising: Does it work for everyone? International Journal of Mobile Marketing, 4(2), 28-35.

Nawi, N. B., Nasir, N. B. \& Mamun, A. A. (2016). Factors contributing to the acceptance of social media as a platform among student entrepreneurs: A review. Mediterranean Journal of Social Sciences, 7(2), 42-51.

Noble, S. M., Haytko, D. L., \& Phillips, J. (2009). What drives college-age Generation Y customers? Journal of Business Research, 62(6), 617-628.

Number of monthly active WhatsApp users worldwide from April 2013 to December 2017 (in millions). Available from: https://www.statista.co $\mathrm{m} /$ statistics/260819/number-of-monthly-active-whatsapp-users/

Olmstead, K. (2014, April 29). Mobile apps collect information about users, with wide range of permissions. Pew Research Center. http:// www.pewresearch.org/fact-tank/2014/04/29/mobile-apps-collectinformation-about-users-with-wide-range-of-permissions/

Parreño, J. M., Sanz-Blas, S., Ruiz-Mafé, C., \& Aldás-Manzano, J. (2013). Key factors of teenagers' mobile advertising acceptance. Industrial Management \& Data Systems, 113(5), 732-749.

Reuters Institute. (2018). Digital News Report 2018. Retrieved from http:// media.digitalnewsreport.org/wpcontent/uploads/2018/06/digital-newsreport-2018.pdf 
Saadeghvaziri, F. (2011). Attitude toward advertising: Mobile advertising vs advertising-in-general. European Journal of Economics, Finance and Administrative Sciences. 28(28), 1-7. https://www.researchgate. net/p ublication/287734547.

Salamon, H. \& Abdul Wahab, N. (2010). Penglibatan Pelajar Sebagai Ejen Multi-Level Marketing: Kajian Terhadap Pelajar SPI, 1-7. http://eprints. utm.my/11597/

Salo, J. \& Tahtinen, J. (2009). Special Features of Mobile Advertising and Their Utilization. Mobile Computing: Concepts, methodologies, tools, and applications. http://doi.org/ 10.4018/978-1-60566-054-7.ch151

So, S. (2016). Mobile instant messaging support for teaching and learning in higher education. Internet and Higher Education, 31, 32-42.

Statista. (2019). Most popular global mobile messenger apps as of July 2019, based on number of monthly active users (in millions). https:// www.statista.com/statistics/258749/most-popular-global-mobilemessenger-apps/

Steimle, J. (2016, April 28). 7 Reasons to Start a Business While in College. Entrepreneur. Retrieved from https://www.entrepreneur.com/article/2 73689.

Swathi, R. M. (2015, October 9). Internet Users in Malaysia Are More Active on WhatsApp and Facebook Than Those in US and UK. Retrieved from https://dazeinfo.com/2015/10/09/facebook-whatsapp-wechat-usagemalaysia-us-uk-china-instant-messaging-report/

Ting, H., Wong, W., Cyril de Run, E. \& Lau, S. (2015). Believes about the use of Instagram: An exploratory study. International Journal of Business and Innovation, 2(2), 15-31.

Torok, T. (2015, April 18). 5 Reasons to Use Instant Messaging Apps for Marketing. SocialMediaToday. Retrieved from http://www.socialmed iatoday.com/marketing/2015-04-18/5-reasons-use-instant-messagingapps-marketing. 
Ugwu, C. L. \& Anekwe, J. U. (2018). Attitude of millennial generation towards the usage of social media devices in Nigerian universities. Research on Humanities and Social Sciences, 8(8), 101-112.

Ying, T. \& Khe, F. H. (2017). Is mobile instant messaging (MIM) useful in education? Examining its technological, pedagogical, and social affordances. Educational Research Review, 21, 85-104.

Yingjiao, X. \& Paulins, V. A. (2015). College students' attitudes toward shopping online for apparel products. Journal of Fashion Marketing and Management: An International Journal, 9(4), 420 - 433. 